\title{
Response of anestrous ewes to the ram effect after follicular wave synchronization with a single dose of estradiol-17 $\beta$
}

\author{
Rodolfo UnGERFELD ${ }^{\mathrm{a}, \mathrm{b} *}$, Ana L. DAGO ${ }^{\mathrm{a}}$, Edgardo RUBIANES ${ }^{\mathrm{c}}$, \\ Mats FORSBERG ${ }^{b}$
}

\begin{abstract}
a Departamento de Fisiología, Facultad de Veterinaria, Lasplaces 1550, Montevideo 11600, Uruguay b Centre for Reproductive Biology, Department of Clinical Chemistry, Faculty of Veterinary Medicine, Swedish University of Agricultural Sciences, Uppsala, Sweden

c Departamento de Producción Animal, Facultad de Agronomía, Montevideo, Uruguay
\end{abstract}

(Received 22 July 2003; accepted 9 December 2003)

\begin{abstract}
Anestrous ewes respond to the introduction of rams with either an ovulation within 23 days that may be followed by luteal phases of normal or short length, with delayed ovulations (56 days later), or with the luteinization of follicles. The aim of this work was to study the relationship between the growth status of the largest follicle present when rams are introduced and the type of ovarian response in non-treated ewes and in ewes treated with estradiol-17 $\beta$ before ram introduction. Thirteen anestrous Corriedale ewes were divided into 2 groups: E2 $(n=7)$ and $\mathrm{C}(n=$ 6). The E2 ewes received a single dose of $50 \mu \mathrm{g}$ estradiol-17 $\beta 5$ days before the introduction of the rams to synchronize the onset of their follicle waves, while $\mathrm{C}$ ewes remained untreated. When the rams were introduced, all E2 ewes had the largest follicle in a growing stage in contrast with the $\mathrm{C}$ ewes ( 3 out of $6 ; P<0.05$ ). Five $\mathrm{C}$ and $4 \mathrm{E} 2$ ewes ovulated after the introduction of the rams (Day $3.4 \pm 0.4$ for $\mathrm{C}$ vs. $4.8 \pm 0.3$ for E2 ewes, respectively, $P<0.05$ ). Only one ewe from each group developed a normal luteal phase; $4 \mathrm{C}$ and $3 \mathrm{E} 2$ ewes had short luteal phases. One $\mathrm{C}$ ewe and $2 \mathrm{E} 2$ ewes had short luteal phases originating from follicles that did not ovulate. After the first luteal phase, all ewes returned to anestrus without a second ovulation or luteal phase. The remaining E2 ewe did not ovulate or show any changes in progesterone serum concentrations. We conclude that the growth status of the largest follicle alone does not determine the ovarian responding pattern of anestrous ewes to the ram effect.
\end{abstract}

follicular dynamics / ultrasound / ram stimulus / ovulation / non-breeding season

\section{INTRODUCTION}

The reproductive response of anestrous ewes to the introduction of rams (the ram effect) has been known since the 1940s [1]. In brief, if anestrous ewes are preconditioned by a period of isolation, the introduction of rams induces changes in their reproductive physiology: LH pulsatility is increased, and ovulation is induced in many of the ewes (for a review see [2]). This ovulation is not associated with estrous behavior. In some of the ewes, the first estrus appears in conjunction with the second ovulation 17 to 20 days after ram introduction. In others, there is at first a short luteal phase

\footnotetext{
* Corresponding author: piub@internet.com.uy
} 
(4-5 days), then a second ovulation also without signs of estrus, followed by a luteal phase of normal duration. Thereafter, another ovulation associated with estrus occurs. The existence of delayed ovulations was originally suggested by Fulkerson et al. [3] and confirmed with laparoscopic [4] and ultrasonographic [5] observations. In our previous experiment [5], we also observed that, in some ewes, luteal concentrations of progesterone are associated with the development of luteinized anovulatory follicles, as was previously reported by Knight et al. [6]. These different patterns of ovarian response lead to a highly characteristic bimodal pattern in the display of estrus after ram exposure and in which there are 2 peaks of estrus in the flock, 17 to 20 and 21 to 25 days later [2].

As in cows [7], follicular growth in ewes occurs in a wave pattern (for review see [8]). The follicular waves emerge approximately every 5 days during the estrous cycle in the breeding season [9]. This wave pattern continues during the non-breeding season in anestrous ewes [10,11]. As in cattle (for review see [12]), follicle waves are preceded by a transient increase in FSH concentrations that stimulates follicle wave emergence during the breeding [13-15] and non-breeding seasons [16]. It has been shown that the ovarian response to a $\mathrm{GnRH}$ challenge is related to the specific growth phase of the largest follicle present in the ovaries during the breeding and the nonbreeding seasons [17, 18]. However, no attempts have been made to test whether a similar relationship between follicular status and ovarian response occurs when the ewe's pituitary-hypothalamus axis is challenged with the ram effect.

In cattle, the administration of estradiol suppresses follicular growth and results in the emergence of a new follicular wave at a consistent interval ( $\sim 4$ days; for review see [19]). However, there is little information about the effects of estradiol on follicular dynamics in ewes. Administration of estradiol-17 $\beta$ to anestrous ewes induces an
LH surge (for a review see [20]) and causes regression of the dominant follicle and the emergence of a new follicular wave approximately 3 days later [21]. The aim of this work was to study the relationship between the growth status of the largest follicle present when rams are introduced and the pattern of ovarian response in non-treated ewes and in ewes treated with estradiol-17 $\beta$ before ram introduction.

\section{MATERIALS AND METHODS}

\subsection{Animals and animal management}

The experiment was conducted within the Department of Physiology, Faculty of Veterinary Science, Montevideo, Uruguay $\left(35^{\circ} \mathrm{S}\right)$ during November (mid-seasonal anestrus). Fourteen adult multiparous Corriedale ewes weighing $48.6 \pm 2.1 \mathrm{~kg}$ and with a body condition of $3.5 \pm 0.2$ (scale 1 5) (mean \pm SE) were used. The ewes were moved to the Department of Physiology and isolated (sight, sound, smell) from the rams for one month. The animals received a diet meeting INRA sheep maintenance standards: water and alfalfa hay $(8.4 \% \mathrm{CP}$ and $58.1 \%$ crude fiber on the basis of DM) ad libitum, plus $500 \mathrm{~g}$ of pellets made from oats, barley, and wheat (12\% CP). They were kept outdoors with natural daylight (14L/10D) in sheltered pens $(40 \mathrm{~m} \times 40 \mathrm{~m})$, and indoor box stalls $(3 \mathrm{~m} \times 3 \mathrm{~m})$ were used when required for handling. All animal experimentation was performed in compliance with the regulations set by the National Board for Laboratory Animals in Sweden (Swedish University of Agricultural Sciences, Uppsala, Sweden).

After verification of anestrous status (ultrasonography and progesterone concentrations), 1 ewe was removed because it had a luteinized follicle. The remaining 13 ewes were divided into 2 homogeneous groups according to weight and body condition. Seven ewes (E2 group) received an im injection of $50 \mu \mathrm{g}$ estradiol-17 $\beta$ (Sigma, 
E8875, St. Louis, MO, USA) in $0.5 \mathrm{~mL}$ of corn oil on Day -5 (Day $0=$ introduction of the rams); the other 6 ewes remained without treatment and served as a control group (group C). On Day 0, 3 adult, sexually experienced Corriedale rams provided with markers were introduced to the ewes. Because anestrous Corriedale ewes subjected to the ram effect express maximum reproductive response when estrous ewes are introduced together with the rams [22], another 8 ewes were brought into estrus by an im injection of 350 IU of eCG (Novormón, Syntex, Buenos Aires, Argentina) after a 6-day priming with intravaginal sponges containing $60 \mathrm{mg}$ of medroxyprogesterone acetate (Syntex, Buenos Aires, Argentina), and were joined at the same time as the rams. Estrus was checked daily from Day 0 until Day 23. Although specific behavioral tests were not performed, the rams showed very low libido, with very few matings seen with ewes in hormonally induced estrus.

\subsection{Blood collection}

Blood was collected from the jugular vein of all animals daily from Day -9 to -5 ; every $4 \mathrm{~h}$ from $1 \mathrm{~h}$ before estradiol-17 $\beta$ was administered (12:00) for $52 \mathrm{~h}$; daily on Days -2 and -1 ; every $4 \mathrm{~h}$ from the introduction of the rams (12:00) for $56 \mathrm{~h}$; every $12 \mathrm{~h}$ from Days 3 to 8; and then daily until Day 23. The samples were allowed to clot for $1 \mathrm{~h}$ at room temperature before being centrifuged for 10 to $20 \mathrm{~min}$. The serum was stored at $-20^{\circ} \mathrm{C}$ until analysis for hormone content.

\subsection{Ultrasonography}

A single operator performed transrectal ultrasonography daily between Day -9 and Day 15 to monitor the follicles and to characterize the ovarian status. The scanner was an Aloka 500 (Tokyo, Japan), real-time, B mode machine with a $7.5 \mathrm{MHz}$ linear array probe, which was adapted for ovines [17, 18]. During each examination, a sketch of both ovaries was made to record the diameter and position of follicles over $2 \mathrm{~mm}$ in diameter. The observations were also recorded on video using individual videocassettes to verify and correct real-time data. After the locations had been recorded, the sketch was compared with that of the previous day. The growth and regression histories (diameters) of each follicle identified were tabulated daily. Ovulation was detected by the collapse of a follicle over $5 \mathrm{~mm}$. Time of ovulation was defined as the moment of the first observation in which the ovulatory follicle was not present. A follicular wave was defined as the growth of a follicle to $\geq 4.5 \mathrm{~mm}$, singularly or as part of a cohort; the day of emergency of the follicular wave was the day before the follicle was $3 \mathrm{~mm}$ in diameter, with an increase the following day. Follicle growth was calculated by determining the increase of the diameter over 2 consecutive days. A follicle was considered to be in a growing status when it grew $\geq 0.5 \mathrm{~mm}$ the previous day.

\subsection{Hormone assays}

Progesterone was measured in samples taken from Day -9 to -5 ; in 1 sample every $12 \mathrm{~h}$ during the first intensive bleeding period (Day -5 to Day -3 ); on Days -2 and -1 ; every $12 \mathrm{~h}$ from Day 0 to Day 7; and in all samples until Day 23. During the second intensive bleeding period ( 0 to $56 \mathrm{~h}$ ), the 2 previous and consecutive samples were measured when the concentrations in one sample were above $0.5 \mathrm{nmol} \cdot \mathrm{L}^{-1}$ (see luteal phase definition). Progesterone was measured with a direct solid-phase ${ }^{125}$ I RIA method (Count-A-Count TKPG, Diagnostic Products Corporation, Los Angeles, CA, USA). The sensitivity of the assay was $0.1 \mathrm{nmol} \cdot \mathrm{L}^{-1}$. Estradiol-17 $\beta$, LH, and FSH were measured in all samples. Estradiol$17 \beta$ was measured with a direct solid-phase 125I RIA method (Count-A-Count TKPG, Diagnostic Products Corporation, Los Angeles, CA, USA) as described by Meikle [21]. The sensitivity of the assay was $2 \mathrm{pmol} \cdot \mathrm{L}^{-1}$. LH was measured with a 
liquid-phase RIA previously validated for ovine serum [23]. The detection limit of the assay was $0.6 \mu \mathrm{g} \cdot \mathrm{L}^{-1}$. FSH concentration was analyzed in all samples with a liquidphase RIA previously validated for ovine serum [21]. The sensitivity of the assay was $0.5 \mu \mathrm{g} \cdot \mathrm{L}^{-1}$. The inter-assay and intra-assay coefficients were below $10 \%$ for all assays.

\subsection{Definitions}

An LH surge was defined as being at least 8 times higher than the basal levels (mean value of all samples). Luteal activity was defined as the presence of progesterone concentrations above $1.5 \mathrm{nmol} \cdot \mathrm{L}^{-1}$ in 4 or more consecutive samples when concentrations were measured every $12 \mathrm{~h}$, or above $0.9 \mathrm{nmol} \cdot \mathrm{L}^{-1}$ in at least 5 consecutive samples when the values were measured every $4 \mathrm{~h}$. A normal luteal phase was defined as the presence of luteal activity for at least 10 days; a short luteal phase was defined as luteal activity for no more than 4 days.

\subsection{Statistical analysis}

The size of the largest follicle and days of follicular wave emergence were compared with ANOVA, variances were compared with the Bartlett test, and frequencies were compared with the chi-square test. Hormonal profiles were analyzed with the general linear model procedure of the Statistical Analysis System (1999/2000, [24]) using an analysis of variance for repeated measures after log transformation.

\section{RESULTS}

\subsection{Response to estradiol-17 $\beta$}

Group $(P<0.0001)$, time $(P<0.0001)$, and the interaction between group and time $(P<0.0001)$, influenced estradiol$17 \beta$ concentrations. Estradiol-17 $\beta$ reached maximum concentration in E2 (131 \pm $\left.18 \mathrm{pmol} \cdot \mathrm{L}^{-1}\right) 4 \mathrm{~h}$ after administration
$(P<0.0001)$, declined over $12 \mathrm{~h}(47 \pm$ $9 \mathrm{pmol} \cdot \mathrm{L}^{-1} ; P<0.0001$ ), and reached concentrations similar to the initial concentrations $16 \mathrm{~h}$ after administration (Fig. 1A).

The concentrations of LH differed between groups $(P<0.0001)$, and an interaction between group and time was also observed $(P<0.0001)$. An LH surge ( $31.6 \pm$ $\left.4.8 \mu \mathrm{g} \cdot \mathrm{L}^{-1}\right)$ was observed in all E2 ewes $12 \mathrm{~h}$ after estradiol-17 $\beta$ administration $(P<$ 0.0001 ), maintaining concentrations higher than basal at $16\left(15.8 \pm 6.4 \mu \mathrm{g} \cdot \mathrm{L}^{-1} ; P<\right.$ $0.0001)$ and $20 \mathrm{~h}\left(5.0 \pm 2.1 \mu \mathrm{g} \cdot \mathrm{L}^{-1} ; P<\right.$ 0.005; Fig. 1B), respectively. Between 12 and $20 \mathrm{~h}$ after estradiol-17 $\beta$ administration, the concentrations were higher in the E2 ewes than in the $\mathrm{C}$ ewes $(P<0.0001)$.

The concentrations of FSH differed between groups $(P<0.0001)$, and an interaction between group and time was also observed $(P<0.0001)$. FSH concentrations tended to decrease in E2 ewes in conjunction with maximum estradiol-17 $\beta$ concentrations $\left(8 \mathrm{~h} ; 1.1 \pm 0.1 \mu \mathrm{g} \cdot \mathrm{L}^{-1} ; P=\right.$ $0.06)$, increasing quickly again 12 (8.0 \pm $\left.1.7 \mu \mathrm{g} \cdot \mathrm{L}^{-1} ; P<0.0001\right)$ and $16 \mathrm{~h}(5.8 \pm$ $\left.2.2 \mu \mathrm{g} \cdot \mathrm{L}^{-1} ; P<0.0001\right)$, and returning to basal concentrations $20 \mathrm{~h}$ after estradiol$17 \beta$ administration $\left(2.3 \pm 0.5 \mu \mathrm{g} \cdot \mathrm{L}^{-1}\right.$; Fig. 1C). Twelve and $16 \mathrm{~h}$ after estradiol$17 \beta$ administration, the concentrations were higher in E2 ewes than in C ewes $(P<$ 0.0001).

The last follicular wave observed prior to estradiol-17 $\beta$ administration emerged on Day $-2.0 \pm 0.6$ and on Day $-1.8 \pm 0.5$ in the $\mathrm{E} 2$ and $\mathrm{C}$ groups, respectively (comparison of variances: $P>0.1$ ). The emergence of the first follicular wave after estradiol-17 $\beta$ treatment was more homogeneous in E2 ewes (Day $2.9 \pm 0.1$ ) than in C ewes (Day $1.7 \pm 0.5$ ) (comparison of variances: $P=$ 0.01 ). No ewe ovulated or showed estrous behavior in the period between estradiol$17 \beta$ administration and the introduction of the rams.

When the rams were introduced, the growth status was more homogeneous in E2 ewes than in C ewes (comparison of 


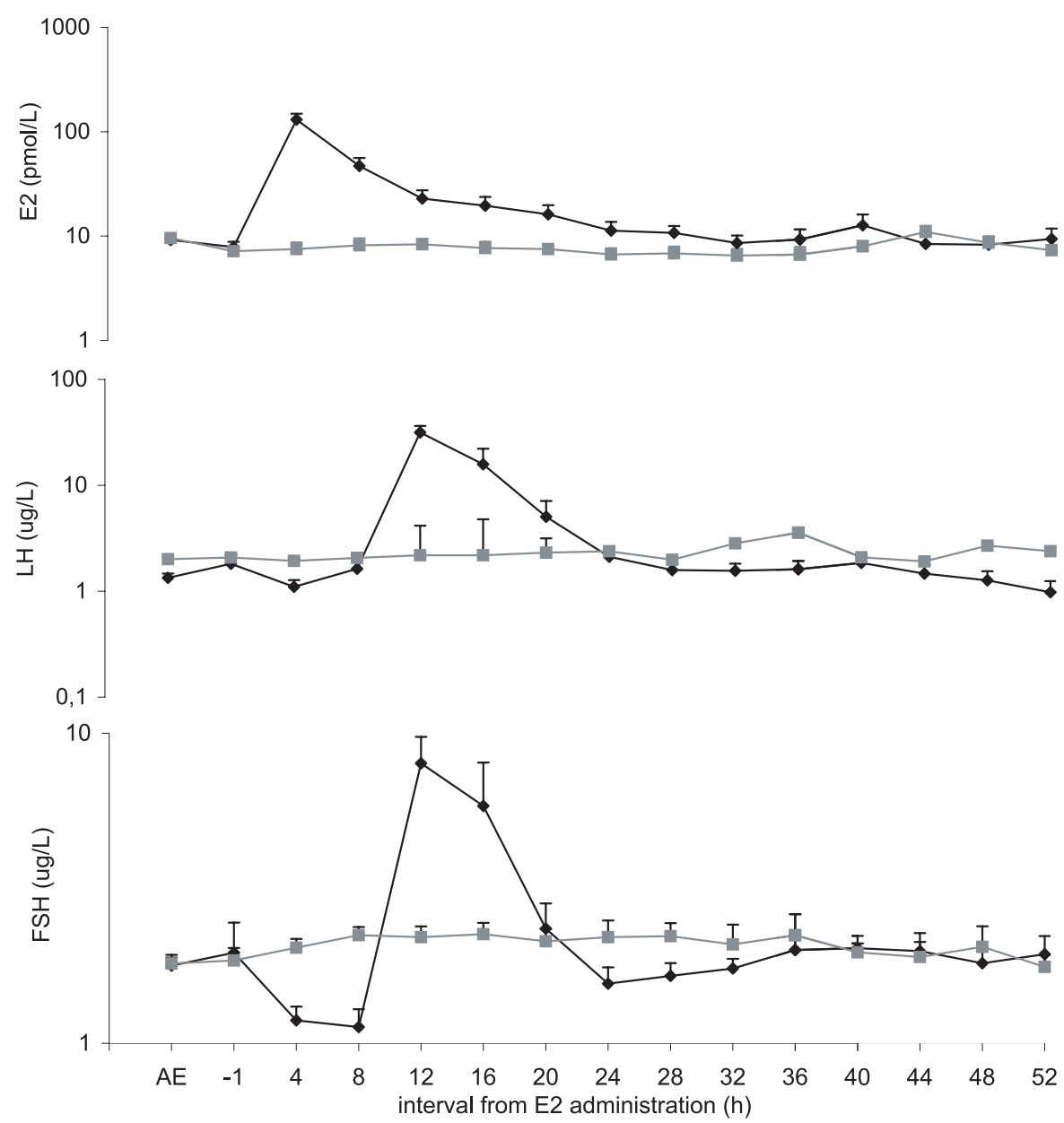

Figure 1. Serum estradiol-17 $\beta$ (A), LH (B) and FSH (C) concentrations in anestrous ewes after the administration of $50 \mu \mathrm{g}$ estradiol-17 $\beta$ (- - ) at $0 \mathrm{~h}$. Control ewes (- -) were not injected. AE is the mean concentration of 5 daily samples collected from 5 days before estradiol-17 $\beta$ administration. The Y-axis is in the logarithmic scale.

variances: $P<0.01$; Tab. I). While the largest follicle was in a growing stage in all E2 ewes, this was the case in only half of the $\mathrm{C}$ ewes $(7 / 7$ vs. $3 / 6 ; P<0.05)$. The diameter of the largest follicle present in the ovaries when the rams were introduced was larger in the $\mathrm{C}$ than in the $\mathrm{E} 2$ ewes $(P<0.001$; Tab. I $)$.

\subsection{Response to rams}

No E2 or C ewes were marked (displayed estrus) during the 23-day experimental period.

Five $\mathrm{C}$ and 4 E2 ewes ovulated after the introduction of the rams. Ovulation occurred earlier in group $\mathrm{C}$ than in group E2 
Table I. Characteristics of the largest follicle present when rams were introduced and ovarian responses. NLP: luteal phase of normal length; SLP: short luteal phase; LP: luteal phase.

\begin{tabular}{lccc}
\hline & C & E2 & $P$ \\
\hline Largest follicle present at ram introduction & & & \\
Day of emergence* & $1.7 \pm 0.5$ & $2.9 \pm 0.1$ & n.s. \\
Growth the day before (mm)* & $0.3 \pm 0.3$ & $0.6 \pm 0.1$ & n.s. \\
Growing phase & $3 / 6$ & $7 / 7$ & $<0.05$ \\
Diameter when rams were introduced & $4.7 \pm 0.1$ & $3.7 \pm 0.1$ & $<0.001$ \\
Responses to rams & & & \\
Ovulated & $5 / 6$ & $4 / 7$ & n.s. \\
Day of ovulation & $3.4 \pm 0.4$ & $4.8 \pm 0.3$ & $<0.05$ \\
Growth the day before (mm) & $0.5 \pm 0.4$ & $0.7 \pm 0.6$ & n.s. \\
Diameter at ovulation (mm) & $5.5 \pm 0.3$ & $5.9 \pm 0.7$ & n.s. \\
NLP & $1 / 5$ & $1 / 4$ & n.s. \\
SLP & $4 / 5$ & $3 / 4$ & n.s. \\
LP from non-ovulatory follicles & $1 / 6$ & $2 / 7$ & n.s. \\
\hline
\end{tabular}

* Variances are significantly different: $P<0.01$.

$(P<0.05 ;$ Tab. I). Only one ewe from each group developed a normal luteal phase; $4 \mathrm{C}$ and 3 E2 ewes had short luteal phases. One $\mathrm{C}$ ewe and $2 \mathrm{E} 2$ ewes, that did not ovulate had short luteal phases originating from follicles that did not ovulate. After the first luteal phase, all ewes returned to anestrus without a second ovulation or luteal phase. The remaining E2 ewe did not show ovulation or changes in progesterone serum concentrations during the studied period.

When the ewes were regrouped according to those whose follicles were in the growing stage when the rams were introduced $(n=10)$ or not $(n=3), 7$ of the ewes that had a growing follicle ovulated; 2 of them had normal luteal phases and 5 had short luteal phases; 2 of them had short luteal phases provoked by follicles that did not ovulate. The 3 ewes that did not have the largest follicles in a growing phase when the rams were introduced had short luteal phases, 2 of them from ovulatory follicles and the other from a non-ovulatory follicle.

The characteristics of the largest follicle present when the rams were introduced were not different between the ewes that ovulated and those that did not ovulate. The largest follicle grew $0.4 \pm 0.2 \mathrm{~mm}$ and $0.4 \pm$ $0.2 \mathrm{~mm}$ the day before the introduction of the rams, and had a diameter of $4.1 \pm$ $0.2 \mathrm{~mm}$ and $4.1 \pm 0.3 \mathrm{~mm}$ when the rams were introduced (the ewes that ovulated and the ewes that did not ovulate respectively; n.s.)

Estradiol-17 $\beta$ concentrations increased in $C$ ewes that ovulated from $9 \pm 1 \mathrm{pmol} \cdot \mathrm{L}^{-1}$ to a maximum of $16 \pm 2 \mathrm{pmol} \cdot \mathrm{L}^{-1}(P<$ $0.001)$ at $56.6 \pm 1.6 \mathrm{~h}$. In the E2 ewes that ovulated, the concentrations increased from $8 \pm 1 \mathrm{pmol} \cdot \mathrm{L}^{-1}$ to a maximum of $14 \pm$ $2 \mathrm{pmol} \cdot \mathrm{L}^{-1}(P<0.05)$ at $60.0 \pm 5.3 \mathrm{~h}$. There were no significant differences in the estradiol-17 $\beta$ profiles between $\mathrm{C}$ and $\mathrm{E} 2$ ewes $(P>0.1)$.

The concentrations of FSH increased in the $\mathrm{C}$ ewes that ovulated from $1.7 \pm$ $0.2 \mathrm{ng} \cdot \mathrm{mL}^{-1}$ to a maximum of $2.3 \pm$ $0.4 \mu \mathrm{g} \cdot \mathrm{L}^{-1}(P<0.05)$ at $61.8 \pm 12.6 \mathrm{~h}$. In the E2 ewes that ovulated, the FSH concentration was $2.1 \pm 0.2 \mu \mathrm{g} \cdot \mathrm{L}^{-1}$, increasing to a maximum of $4.0 \pm 1.3 \mu \mathrm{g} \cdot \mathrm{L}^{-1}$ (NS, $P>0.1)$ at $82.0 \pm 22.7 \mathrm{~h}$. There were no 


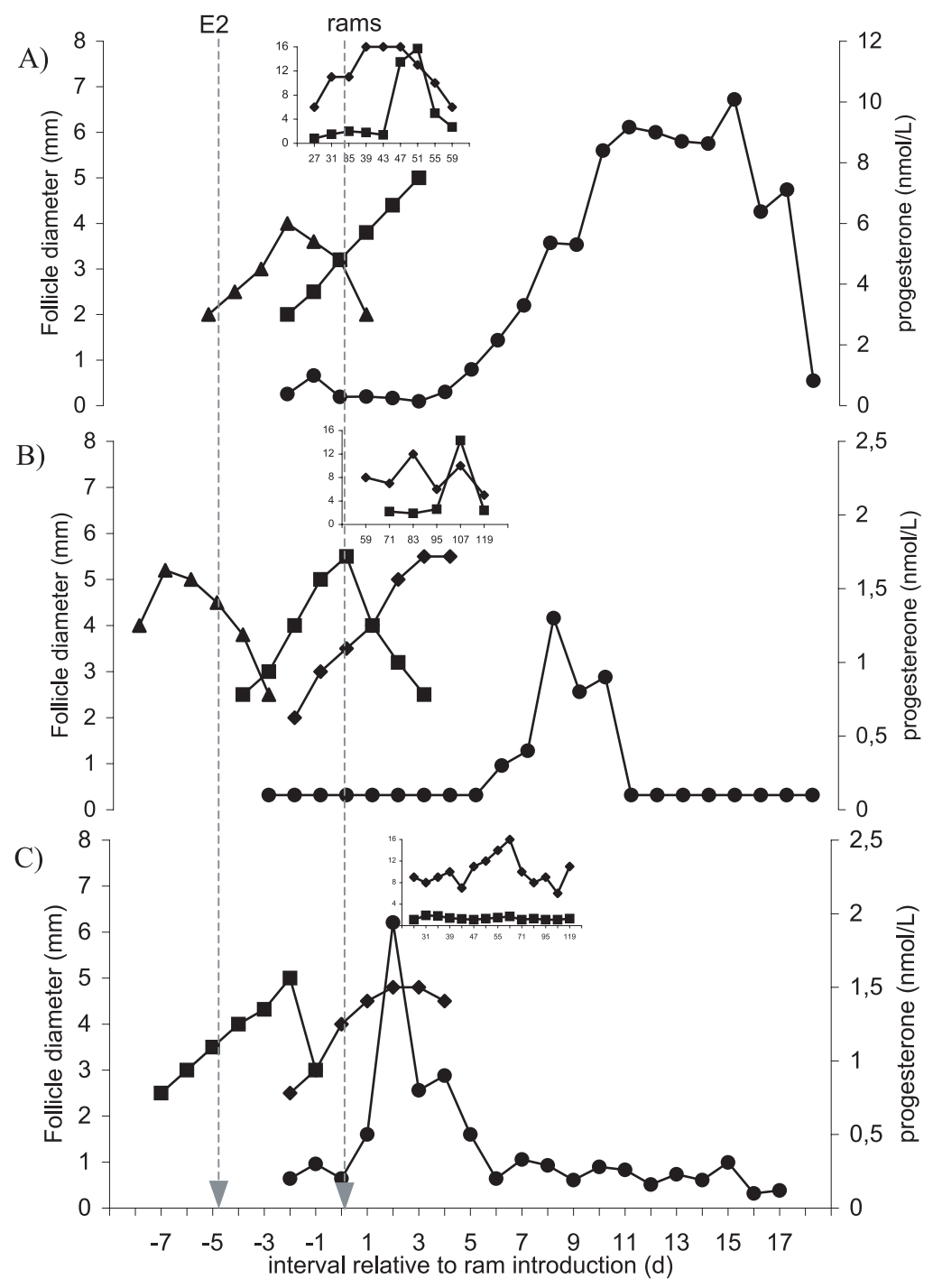

Figure 2. Follicle profiles (- $\mathbf{\Delta}-,-\mathbf{-}-,-\boldsymbol{-})$, and progesterone (- - ) responses in 3 anestrous ewes that were treated with $50 \mu \mathrm{g}$ estradiol-17 $\beta$ (first arrow) 5 days before the introduction of rams (second arrow). In these ewes, the largest follicle emerged 2 days before ram exposure. This follicle responded with the following: (A) a normal luteal phase, (B) a short luteal phase after an ovulation, and (C) a short luteal phase without ovulation. Estradiol-17ß (- -) and LH (-ם-) surges are shown in the inset graphs when corresponding.

significant differences in FSH profiles between the $\mathrm{C}$ and $\mathrm{E} 2$ ewes $(P>0.1)$.

There was no relationship between the follicle status and ovarian response. Figure 2 shows the follicle profiles and LH, estradiol-17 $\beta$, and progesterone patterns in the three E2 ewes in which the largest follicle emerged on Day 2 and responded with a 
normal luteal phase (A), a short luteal phase after an ovulation (B), and a short luteal phase without a previous ovulation (C).

\section{DISCUSSION}

We observed a high synchronization of follicular wave onset approximately 3 days after estradiol-17 $\beta$ administration, confirming previous findings [21]. However, we did not observe a direct relation between the follicular status and the ovarian response to the introduction of the rams. In fact, even the largest follicle was in a growing and homogeneous status in all E2 ewes, the ovarian responses were similar to those observed in Cewes, which, since no attempts were made to manage the follicular growth, presented a random status of their largest follicle when the rams were introduced. The only difference provoked by estradiol-17 $\beta$ was a delay on the ovulation of the E2 ewes, which agrees with earlier observations of Martin [25]. We did not observe any relation between the ovarian response according to the status of the largest follicle present when the rams were introduced, despite the ewes being treated or not with estradiol$17 \beta$. In previous experiments, we observed that the largest follicle responded differently to a GnRH challenge according to the growing status [17, 18]. However, our results agree with those of Bartlewski et al. [26], who observed that large follicles of a similar age and a similar growth stage respond with different ovarian patterns to GnRH administration. When the ewes that ovulated were analyzed retrospectively, despite the original group to which they belonged, there were no differences on the follicular status when the rams were introduced. One possible explanation for our results is that while in Rubianes et al. [17, 18] experiments, the ewes received a pharmacological stimulation, in the present experiment the response reflected how the ewe's hypotha- lamic-pituitary axis responded to the ram stimuli. Also the possible effects of the $\mathrm{LH}$ and FSH surges provoked by estradiol-17 $\beta$ administration on the characteristics of the largest follicle should be considered.

The ewes responded with a high incidence of short luteal phases (overall, 10 from 13 stimulated ewes). This result agrees with Perkins and Fitzgerald [27], who observed a high incidence of short luteal phases after the introduction of low libido rams. It remains to be elucidated whether this is related to an insufficient $\mathrm{LH}$ response in the ewes when low libido rams are used. The short luteal phases in E2 ewes originated from follicles ovulating approximately 5 days after the introduction of the rams. Although the occurrence of delayed ovulations followed by normal luteal phases has been previously reported $[4,5]$, we now report the existence of delayed ovulations followed by short luteal phases.

All of the ewes that show ovarian responses after the introduction of the rams returned to anestrus without a second ovulation or luteal phase, and without displaying estrous behavior during the expected period for ram-stimulated ewes (Days 1725). We have observed similar outcomes in a previous experiment done under laboratory conditions [5], but we obtained different results when the ewes from the same flock were stimulated under field conditions in the same anestrous period (Exps. 1 and 2 from [28]). Sheep show a stress response after transportation [29], and during adaptation to a new environment [30]. Although maximum attempts were made to minimize the possible negative effects of transportation and the joining of the rams, these may not have been enough to eliminate the problem.

We conclude that the growth status of the largest follicle alone does not determine the ovarian responding pattern of anestrous ewes to the ram effect. 


\section{ACKNOWLEDGMENTS}

We thank Bettina Carbajal, Leticia Silva, César Niell, and Fernando Clivell for help with animal management; Milton Pintos for taking care of the animals; Teresa de Castro and Alejo Menchaca for critical comments on the manuscript; Elsa Garófalo and Celia Tasende for estradiol-17 $\beta$ preparation. Thanks are also due to Marie-Anne Carlsson and Åsa Karlsson for RIA analyses, and to Dr. A.F. Parlow and Dr. J. Roser for supplying hormone and antibody preparations for the LH and FSH assays. Financial support was given by CIDEC (Facultad de Veterinaria, Uruguay), CSIC (Universidad de la República, Uruguay), the Department of Clinical Chemistry, SLU (Uppsala, Sweden), and the FNI (CONICYT, Uruguay).

\section{REFERENCES}

[1] Underwood EJ, Shier FL, Davenport N. Studies in sheep husbandry in Western Australia V. The breeding season of Merino, crossbreed and British Breeds ewes in the agricultural districts. J Agric West Aust 1944, 11:Series 2, 135-143.

[2] Martin GB, Oldham CM, Cognié Y, Pearce DT. The physiological responses of anovulatory ewes to the introduction of rams - a review. Livest Prod Sci 1986, 15: 219-247.

[3] Fulkerson WJ, Adams NR, Gherardi PB. Ability of castrated male sheep treated with oestrogen or testosterone to induce and detect oestrus in ewes. Appl Anim Ethol 1981, 7: 57-66.

[4] Cushwa TW, Bradford GE, Stabenfeldt GH, Berger YM, Dally MR. Ram influence on ovarian and sexual activity in anestrous ewes: effects of isolation of ewes from rams before joining and date of ram introduction. J Anim Sci 1992, 70: 1195-1200.

[5] Ungerfeld R, Pinczak A, Forsberg M, Rubianes E. Ovarian and endocrine responses of Corriedale ewes to "ram effect" in the non-breeding season. Can J Anim Sci 2003, 82: 599602.

[6] Knight TW, Tervit HR, Fairclough RJ. Corpus luteum in ewes stimulated by rams. Theriogenology 1981, 15: 183-190.

[7] Bo GA, Baruselli PS, Martínez MF. Pattern and manipulation of follicular development in Bos indicus cattle, Anim Reprod Sci 2003, 78: 307-326.
[8] Evans ACO. Ovarian follicle growth and consequences for fertility in sheep. Anim Reprod Sci 2003, 78: 289-306.

[9] Ginther OJ, Kot K, Wiltbank MC. Associations between emergence of follicular waves and fluctuations in FSH concentrations during the estrous cycle in ewes. Theriogenology 1995, 43: 689-703.

[10] Bartlewski PM, Beard AP, Cook SJ, Rawlings NC. Ovarian follicular dynamics during anestrus in ewes. J Reprod Fertil 1998, 113: 275-285.

[11] Souza CJH, Campbell BK, Baird DT. Follicular dynamics and ovarian steroid secretion in sheep during anoestrus. J Reprod Fertil 1996, 108: 101-106.

[12] Mihm M, Bleach ECL. Endocrine regulation of ovarian antral follicle development in cattle. Anim Reprod Sci 2003, 78: 217-237.

[13] Evans ACO, Flynn JD, Duffy P, Knight PG, Boland MP. Effects of ovarian follicle ablation on FSH, oestradiol and inhibin A concentrations and growth of other follicles in sheep. Reproduction 2002, 123: 59-66.

[14] Gibbons JR, Kot K, Thomas DL, Wiltbank MC, Ginther OJ. Follicular and FSH dynamics in ewes with a history of high and low ovulation rates. Theriogenology 1999, 52: 1005-1020.

[15] Viñoles C, Forsberg M, Banchero G, Rubianes E. Ovarian follicular dynamics and endocrine profiles in Polwarth ewes with high and low body condition. Anim Sci 2002, 74: 539-545.

[16] Evans ACO, Duffy P, Quinn KM, Knight PG, Boland MP. Follicular waves are associated with transient fluctuations in FSH but not oestradiol or inhibin-A concentrations in anoestrous ewes. Anim Sci 2001, 72: 547554.

[17] Rubianes E, Beard A, Dierschke DJ, Bartlewski P, Adams GP, Rawlings NC. Endocrine and ultrasound evaluation of the response to PGF 2 and GnRH given at different stages of the luteal phase in cyclic ewes. Theriogenology 1997, 48: 1093-1104.

[18] Rubianes E, de Castro T, Ungerfeld R, Meikle A, Rivero A. Ovarian response after a $\mathrm{GnRH}$ challenge in seasonally anestrous ewes. Can J Anim Sci 1999, 77: 727-730.

[19] Bo GA, Baruselli PS, Moreno D, Cutaia L, Caccia M, Tribulo R, Tribulo H, Mapletoft RJ. The control of follicular wave development for self-appointed embryo transfer programs in cattle. Theriogenology 2002, 57: 53-72. 
[20] Martin GB. Factors affecting the secretion of luteinizing hormone in the ewe. Biol Rev 1984, 59: 1-87.

[21] Meikle A, Forsberg M, Garófalo EG, Carlsson MA, Lundeheim N, Rubianes E. Circulating gonadotrophins and follicular dynamics in anestrous ewes after treatment with estradiol17ß. Anim Reprod Sci 2001, 67: 79-90.

[22] Rodríguez Iglesias RM, Ciccioli N, Irazoqui $\mathrm{H}$, Rodriguez BT. Importance of behavioural stimuli in ram-induced ovulation in seasonally anovular Corriedale ewes. Appl Anim Behav Sci 1991, 30: 323-332.

[23] Forsberg M, Tagle R, Madej A, Molina JR, Carlsson M-A. Radioimmunoassay of bovine, ovine and porcine $\mathrm{LH}$ with a monoclonal antibody and a human tracer. Acta Vet Scand 1993, 34: 255-262.

[24] SAS. 1999-2000. Statistical Analysis Systems, Version 8.

[25] Martin GB. Ram-induced ovulation in seasonally anovular Merino ewes: effect of oestradiol on the frequency of ovulation, oestrus and short cycles. Theriogenology 1979, 12: 283-287.
[26] Bartlewski PM, Beard AP, Chapman CL, Nelson ML, Palmer B, Aravindakshan J, Cook SJ, Rawlings NC. Ovarian responses in gonadotrophin-releasing hormone-treated anoestrous ewes: follicular and endocrine correlates with luteal outcome. Reprod Fertil Dev 2001, 13: 133-142.

[27] Perkins A, Fitzgerald JA. The behavioral component of the ram effect: the influence of ram sexual behavior on the induction of estrus in anovulatory ewes. J Anim Sci 1994, 72: 51-55.

[28] Ungerfeld R, Suárez G, Carbajal B, Silva L, Laca M, Forsberg M, Rubianes E. Medroxyprogesterone primings and response to the ram effect in Corriedale ewes during the nonbreeding season. Theriogenology 2003, 60: $35-45$.

[29] Parott RF, Hall SJG, Lloyd DM. Heart rate and stress hormone responses of sheep to road transport following two different loading procedures. Anim Welfare 1998, 7: 257267.

[30] Gudev D, Kolev A, Madzharov I. Adaptation period of rams after transportation and environment changes. Zhivot Nau 1994, 31: 227228. 